\title{
Morpho-physiological Basis of Yield Performance of Early Maturing Rice Varieties in Bangladesh
}

\author{
Md. Babul Akter ${ }^{1 *}$, Md. Tariqul Islam ${ }^{1}$, Md. Monjurul Alam Mondal ${ }^{1}$, \\ Md. Imdadul Hoque ${ }^{2}$, Md. Kamruzzaman ${ }^{3}$, Mahmudul Hassan Nafis $^{4}$, \\ Afia Sultana ${ }^{4}$ and Md. Shamsher Ali $^{1}$
}

${ }^{1}$ Crop Physiology Division, Bangladesh Institute of Nuclear Agriculture, BAU Campus, Mymensingh2202, Bangladesh.

${ }^{2}$ ARED Division, Bangladesh Institute of Nuclear Agriculture, BAU Campus, Mymensingh-2202

${ }^{4}$ Bangladesh Agricultural University, Mymensingh-2202, Bangladesh.

Authors' contributions

This work was carried out in collaboration among all authors. Authors MBA, MTI and MMAM designed the experiment. Authors MBA, MIH, MK and MHN conducted the field experiment and did the statistical analysis. Authors AS and MBA collected the related papers, wrote the first draft and author $M S A$ revised the manuscript. All authors read and approved the final manuscript.

Article Information

DOI: $10.9734 / A R R B / 2019 / v 32 i 530097$

(1) Dr. Md. Aminur Rahman, Professor, World Fisheries University Pilot Programme, Pukyong National University (PKNU),

South Korea. Reviewers:

(1) Anuj Kumar, University of Arkansas, USA. (2) Grace O. Tona, Ladoke Akintola University of Technology, Nigeria. Complete Peer review History: http://www.sdiarticle3.com/review-history/50288

\section{ABSTRACT}

A considerable progress in plant breeding for higher yield is attained mainly through selection of morpho-physiological attributes in rice. The field experiments were conducted at three different locations under sub-tropical conditions with four early maturing rice varieties viz., Binadhan-7, Binadhan-17, BRRI dhan33, and BRRI dhan39 during kharif-2 rice season (Aman; July-October) of 2016 to find out the natural variation in the morpho-physiological attributes contributing to higher grain yield in rice. Morphological parameters on plant height, root structure, tillering ontogeny, internode elongation pattern, flag leaf length, flag leaf width, flag leaf angle, number of primary \& 
secondary rachis, branches and also physiological traits on chlorophyll content, photosynthesis rate, total dry mass, growth rate, number of vascular bundles, harvest index with yield and yield contributing characters were studied. Results indicated that plants having rapid growth and development at early growth stages showed higher chlorophyll content, photosynthesis rate, long flag leaf, number of vascular bundles in $1^{\text {st }}$ internode and also exhibited the increase in the number of grains per panicle resulting higher grain yield. Among the test varieties, Binadhan-17 showed superiority in the most morpho-physiological criteria and higher number of vascular bundles manifesting in higher grain yield. This information may help breeders to identity and develop high yielding rice variety.

Keywords: Morpho-physiology; early maturing; yield and rice varieties.

\section{INTRODUCTION}

Rice (Oryza sativa L.) is one of the most important food crops in the world especially in Asia and African countries [1]. More than $50 \%$ of the world's population took rice as a staple food that provides $45-60 \%$ of the dietary calories [2]. In the last half-century, world rice production has dramatically increased due to genetic and morpho-physiological improvement of traditional varieties or development of high yielding rice varieties. However, rapid population growth and economic development are creating pressures for increase food production. Yield and yield associated traits of different field crops are complex, controlled by various genes and are highly influenced by environmental conditions [3]. It is important that further improvements will be required to fulfill the demand of increasing world populations. Accordingly, improving crop productivity by selecting yield-contributing characters has been an important factor for higher rice production [4]. However, rice grain yield production depend on tiller number per plant, grain number per panicle, grain size, grain fertility, panicle length and rachis branching of the panicle [5].

The utilization of heterosis and variation in plant architecture are considered to be important components in high yielding rice production [6]. Studies have been conducted to increase the fundamental understanding on morphophysiological attributes of the grain yield of rice by many breeders and physiologists, and based on their results they formulated different selection criteria for yield improvement. Thus, their applications have been associated with increased yield. Effect of yield attributing traits on the final grain yield of rice has been extensively studied $[7,8]$. Of them, number of panicles per plant, number of grains per panicle and grain weight directly contribute to the final yield of rice $[9,10,11]$. Besides, there are some other characters like plant height, days to maturity, panicle length etc. also contribute to grain yield [12]. Rice genotypes classified into six groups based on the elongation patterns of the internodes which support the plant to stand [13].

The degree of grain filling in rice spikelet greatly affect by leaf position and orientation. Besides, grain yield in rice was positively associated with physiological attributes such as net assimilation rate (NAR), leaf area index (LAI), photosynthesis, specific leaf weight (SLW) and total dry matter, however, in path co-efficient analysis TDM and Photosynthesis were found most important $[14,15]$. Further, the variety with higher dry matter production come from the roots and shoots which constitute the plant structure that helped in higher grain yield production. The optimum proportion of dry mass production between different parts should be properly partitioned for maximizing the grain yield [16]. Several researchers reported that the genotypes with higher TDM also produced higher yield due to large root system and leaf area $[17,18]$.

In addition, morphological and physiological traits also have the important role on the major improvements in rice yield potential, which ultimately improve the efficiency of resource capture. The high-yielding rice varieties showed higher leaf photosynthetic rates and chlorophyll content [19] and their metabolism regulates the plant development [20]. Photosynthesis is the major factor that makes variation in biomass production and yield [21,22] which stimulus the response of photosynthesis to light such as chlorophyll, flag leaf length, width and angle. Besides, it has been clear that leaf photosynthesis increases $20-30 \%$ grain yield in rice [23]. However, recent studies indicate that growth rate during heading stage is critically related with final yield in rice [24] and a positive relationship between leaf photosynthesis and leaf chlorophyll content has been widely observed in 
rice [25]. However, about $90 \%$ of biomass production is derived from photosynthetic products in crop that increased yields [26]. The leaf length, width and angle are determinant the shape and size of a leaf which control photosynthesis [19]. Flag leaf plays important roles for grain yield through greater carbohydrate translocation from leaf to the spikelet during the grain filling [27]. It is predicted that many of the mechanisms used to improve rice yield potential such as canopy architecture, $\mathrm{HI}$ and total biomass production $[28,29]$.

The trait effect on grain yield is important for plant breeders to recognize promising traits to be selected that can make variations in rice yield production [30,31]. The present study was carried out under sub-tropical condition to know the morpho-physiological causes of yield variation in similar durated modern rice varieties.

\section{MATERIALS AND METHODS}

\subsection{Site Description, Plant Materials and Design}

Field experiments were performed at three agroecological zones of Bangladesh such as Mymensingh, Magura and Pabna districts in Kharif (July-October) season of 2016. Four early maturing rice varieties such as Binadhan-7 (110120 days), Binadhan-17 (112-118 days), BRRI dhan33 (118 days) and BRRI dhan39 (120 days) were used in this study. Average temperature during the cropping season was around $32 \pm 3^{\circ} \mathrm{C}$ (Source: Bangladesh Meteorological Department). The soil status of Mymensingh, Magura and Pabna experimental land is presented in Table 1.

The experiment was laid out in a Randomized Complete Block Design (RCBD) with three replicates. The unit plot size was $3.0 \mathrm{~m} \times 3.0 \mathrm{~m}$. Thirty-five days old seedlings were transplanted on 05 August, 2016. Plant to plant and row to row distance were maintained at $15 \mathrm{~cm}$ and 20 $\mathrm{cm}$, respectively.

\subsection{Fertilizer Application and Cultural Methods}

Urea, triple super phosphate (TSP), muriate of potash (MP) and gypsum were applied at the rate of urea 120, TSP 80 , MP 60 and gypsum 45 $\mathrm{kg} \mathrm{ha}^{-1}$ [32]. All the fertilizers were applied at basal doses during final land preparation except urea. Half of urea was applied at 15 days after transplanting (DAT) and remaining half urea was applied at 45 DAT as top dress. Intercultural operations were done when needed for ensuring proper growth and development of the rice.

\subsection{Parameters Measured}

To study ontogenetic growth characteristics, five harvests were made and the first crop sampling was done at 30 DAT and continued at an interval of 10 days until the crop maturity. Ten plants were randomly selected per plot and uprooted for obtaining data of different parameters. The separated plants were collected and the corresponding dry weights were recorded after oven drying at $80 \pm 2^{\circ} \mathrm{C}$ for 72 hours [33]. Leaf chlorophyll was measured by SPAD meter (Konica Minolta Sensing Inc., Japan) at different DAT. Leaf photosynthesis was measured by Portable Photosynthesis System (Li-Cor LI6400XT, LICOR Inc. Nebraska, USA). The rice plants were harvested when $90 \%$ of the grains became golden yellow in color. At harvest, yield contributing characters and seed yield were recorded from 10 representative plants.

\subsection{Anatomical Features of Peduncle Tissues}

Peduncles were sampled at the ripening stage. The $1^{\text {st }}$ internodes were cut and fixed in FAA solution $(50 \%$ ethanol, $5 \%$ acetic acid, $3.7 \%$ formaldehyde) and stored at $4^{\circ} \mathrm{C}$ following the

Table 1. General characteristics of soil at three different locations

\begin{tabular}{|c|c|c|c|}
\hline Soil characteristics & Mymensingh & Magura & Pabna \\
\hline Textural class & Sandy loam & Silty clay loam & Silty clay loam \\
\hline Organic matter (\%) & $0.84 / 1.17$ & 1.30 & 1.47 \\
\hline Total nitrogen $(\%)$ & 0.07 & 0.06 & 0.12 \\
\hline Available phosphorus (ppm) & 18.5 & 15.2 & 14.6 \\
\hline Exchangeable potassium $\left(\mathrm{emol} \mathrm{kg}^{-1}\right)$ & 0.12 & 0.11 & 0.11 \\
\hline Available sulphur & 18.62 & 18.9 & 19.3 \\
\hline $\mathrm{pH}$ & 6.8 & 7.3 & 6.5 \\
\hline
\end{tabular}


methods described by Akter et al. [34]. The sample was cut using a sharp blade and the sections were stained with $1 \%$ safranin in $30 \%$ ethanol for 30s, followed by two washes with sterile water, then mounted on Superfrost-plus glass slides (Fisher Scientific, Pittsburgh, PA, USA) using glycerin. Finally, the cross sections of peduncle were observed by optical microcopy at 100 magnifications (BX53M/BXFM system microscope, OLYMPUS).

\subsection{Statistical Analysis}

The collected data were analyzed statistically following the analysis of variance (ANOVA) technique and the mean differences were adjusted with Duncan's Multiple Range Test (DMRT) using the statistical computer package program, MSTAT-C [36].

\section{RESULTS AND DISCUSSION}

\subsection{Morphological Traits}

Improvement of rice yield potential controlled by different mechanisms through canopy architecture, $\mathrm{HI}$ and total biomass production $[28,29]$. We evaluated different growth and development of early maturing rice varieties, which make variations in different yield contributing characters. The phenotypic developments were compared from the vegetative to the maturity stage. At the seedling stage, BRRI dhan39 displayed apparently shorter plant than other studied varieties, whereas plant height was almost similar at tillering stage in all varieties. (Figs. $1 \mathrm{~A} \& \mathrm{~B}$ ) and at maturity, Binadhan-17 was the shortest (Fig. 1C \& Table 2). Binadhan-7 and BRRIdhan33 exhibited long and profuse fibrous roots (Fig. 1D) but almost similar heading date was recorded (Table 2). Binadhan-7 produced increased tiller numbers at all growth stages and BRRI dhan39 always produced fewer numbers of tillers (Fig. 2 and Table 2). Finally, Binadhan-17 produced higher grain yield as well straw yield with increased harvest index (Table 2). This suggests that several variations were noted among the early maturing varieties. The harvest index (HI) increased the plant capacity to allocate assimilates into the developed reproductive parts $[35,37]$ that may be useful in selecting crop varieties for higher grain yield [38]. Our observations suggest that Binadhan-17 had more ability to allocate biomass in developing organs for higher yield production.

Table 2. Morphological and yield contributing characters of early maturing four rice varieties

\begin{tabular}{llllllll}
\hline Variety & $\begin{array}{l}\text { Heading } \\
\text { date }\end{array}$ & $\begin{array}{l}\text { Plant } \\
\text { height } \\
\text { (cm) }\end{array}$ & $\begin{array}{l}\text { Tillers } \\
\text { plant }^{-1} \\
\text { (no) }\end{array}$ & $\begin{array}{l}\text { Effective } \\
\text { tillers plant } \\
{ }^{1}(\mathbf{n o})\end{array}$ & $\begin{array}{l}\text { Grain } \\
\text { yield }(\mathbf{t} \\
\left.\text { ha }^{-1}\right)\end{array}$ & $\begin{array}{l}\text { Straw } \\
\text { yield } \\
\left.\text { (t ha }^{-1}\right)\end{array}$ & $\begin{array}{l}\text { Harvest } \\
\text { index } \\
(\%)\end{array}$ \\
\hline Binadhan-7 & October 2 & $94.1 \mathrm{~b}$ & $10.59 \mathrm{a}$ & $9.58 \mathrm{a}$ & $4.22 \mathrm{~b}$ & $5.23 \mathrm{c}$ & $44.66 \mathrm{a}$ \\
Binadhan-17 & October 1 & $89.1 \mathrm{c}$ & $9.58 \mathrm{~b}$ & $8.41 \mathrm{~b}$ & $5.07 \mathrm{a}$ & $5.85 \mathrm{ab}$ & $46.43 \mathrm{a}$ \\
BRRI dhan33 & October 2 & $102.6 \mathrm{a}$ & $7.74 \mathrm{c}$ & $7.37 \mathrm{~b}$ & $4.83 \mathrm{a}$ & $5.77 \mathrm{~b}$ & $45.57 \mathrm{a}$ \\
BRRI dhan39 & October 4 & $103.7 \mathrm{a}$ & $8.99 \mathrm{~b}$ & $8.12 \mathrm{~b}$ & $4.20 \mathrm{~b}$ & $6.10 \mathrm{a}$ & $40.78 \mathrm{~b}$ \\
CV\% & - & 3.38 & 10.94 & 12.96 & 4.70 & 5.15 & 7.31 \\
\hline
\end{tabular}

Common letter(s) in a column on specific treatment do not differ significantly at $5 \%$ level as per DMRT

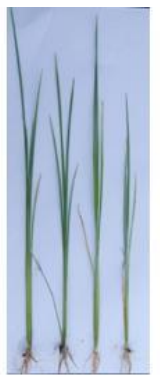

A

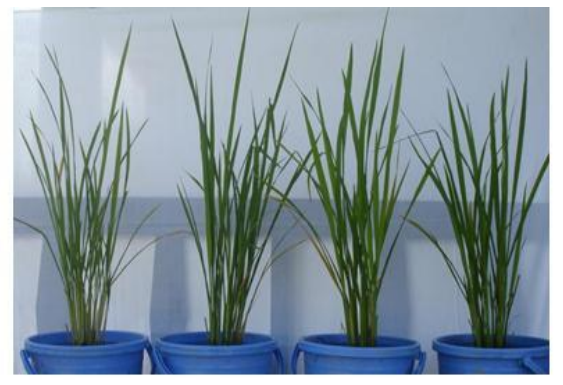

B

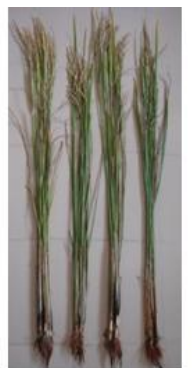

C

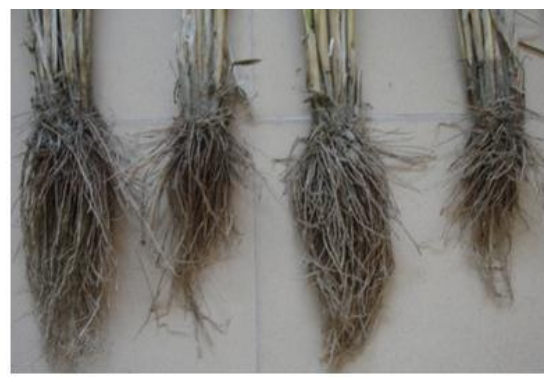

D

Fig. 1. Morphological appearance; A: seedling stage, B: tillering stage, C: maturity stage, D: roots of early maturing rice varieties from left to right; Binadhan-7, Binadhan-17, BRRI dhan33 and BRRI dhan39 respectively 


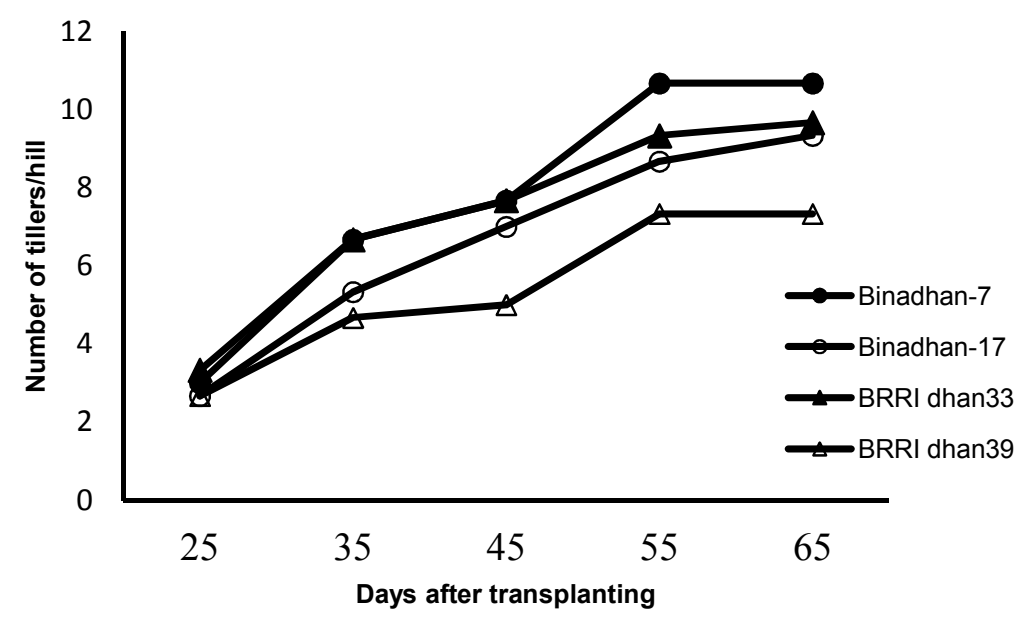

Fig. 2. Ontogenetic tillering pattern of early maturing four rice varieties

Table 3. Comparison of flag leaf in early maturing four rice varieties

\begin{tabular}{llll}
\hline Variety & Leaf angle $\left(^{(}\right)$ & Leaf length $(\mathbf{c m})$ & Leaf width $(\mathbf{c m})$ \\
\hline Binadhan-7 & $9.33 \mathrm{a}$ & $39.28 \mathrm{bc}$ & $1.09 \mathrm{~b}$ \\
Binadhan-17 & $10.00 \mathrm{a}$ & $48.07 \mathrm{a}$ & $1.38 \mathrm{a}$ \\
BRRIdhan33 & $9.83 \mathrm{a}$ & $37.18 \mathrm{C}$ & $1.48 \mathrm{a}$ \\
BRRIdhan39 & $9.8 \mathrm{a}$ & $40.76 \mathrm{~b}$ & $1.38 \mathrm{a}$ \\
CV\% & 3.73 & 2.67 & 5.79 \\
\hline \multicolumn{2}{c}{ Common letter(s) } & in a column on specific treatment do not differ significantly at $5 \%$ level as per DMRT
\end{tabular}

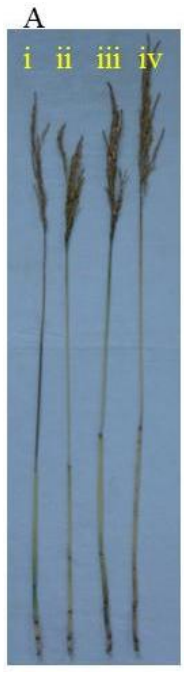

B

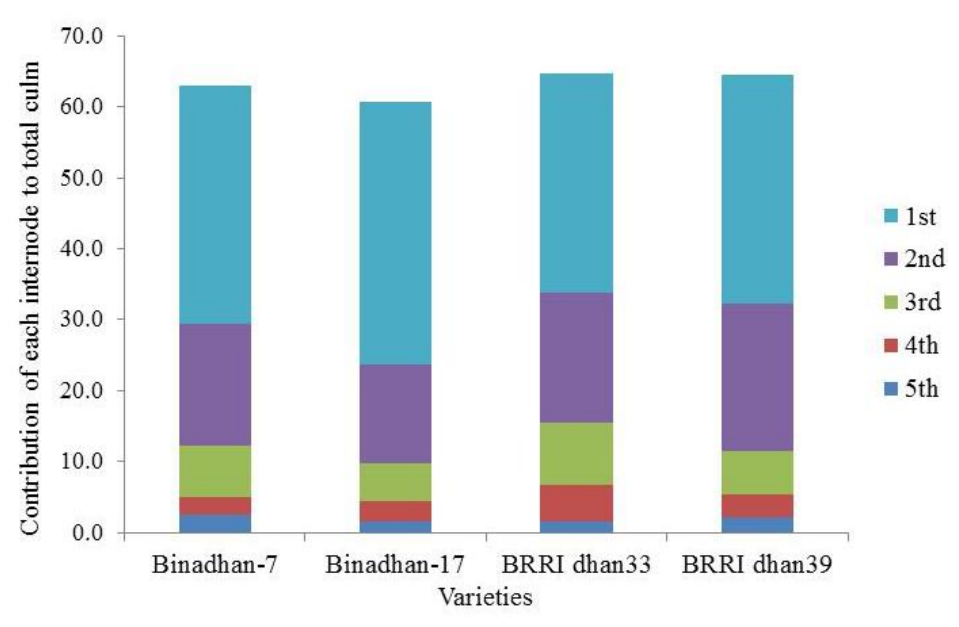

Fig. 3. Internodes elongation patterns; A. Schematic representation of the upper five internodes of four rice varieties i) Binadhan-7, ii) Binadhan-17, iii) BRRI dhan33 and iv) BRRI dhan39 respectively; $B$. Relative contribution of each internode to the total culm length

The relative lengths of each internode of the culm in four varieties are shown in Fig. 3A. All internodes were evenly shortened for all varieties that fit with dn-type of internode elongation pattern, based on the classification by Takeda [13]. Among them, the $2^{\text {nd }}$ internode of Binadhan17 was mostly shortened (Fig. 3A \& B) that may reduce the culm length. 
All the tested cultivars showed significant difference in flag leaf length and width (Table 3). Amongst varieties, Binadhan-17 displayed the longest flag leaf comparing to other varieties, whereas narrow flag leaves were observed in Binadhan-7 (Fig. 4A \& B and Table 3). The flag leaf structure and position of a cultivar determines the amount of photosynthetic activity [39]. It significantly affects grain yield adjusting the canopy structure and other important production parameters $[27,39]$. In the present study, Binadhan-17 had the long and narrow leaves that might help in capturing resource and producing sufficient assimilates.

\subsection{Physiological Traits}

The pattern of chlorophyll content and photosynthesis rate was significantly different among the varieties during the different growth periods. The leaf chlorophyll was higher at tiller start stage (30 DAT) followed by declined at 40 DAT, thereafter leaf chlorophyll gradually increased with age until 60 DAT followed by a decline until maturity in all varieties (Fig. 5). The highest leaf chlorophyll content and photosynthetic rate was observed in Binadhan17 at all growth stages and Binadhan-7 contained the lowest chlorophyll (Fig. 5). The rice yield depends on various processes including photosynthesis rate, conversion of assimilates to biomass and assimilates partitioning [40,41]. Chlorophyll content and photosynthesis rates during plant growth and development are related with high yield [42] that support the insight of increased grain yield production in Binadhan-17.

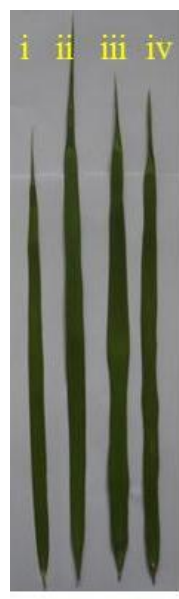

A

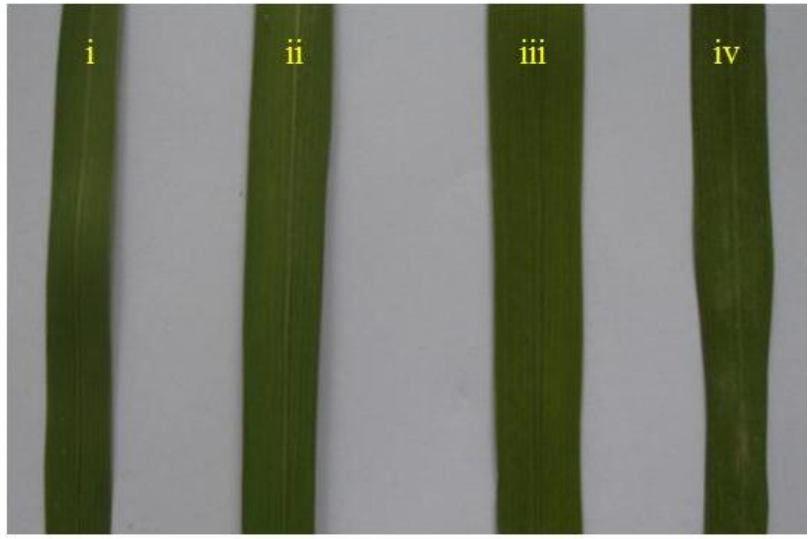

B

Fig. 4. Variations in flag leaf length and breadth; A. Leaf length B. Leaf width of four rice varieties i) Binadhan-7, ii) Binadhan-17, iii) BRRI dhan33 and iv) BRRI dhan39 respectively

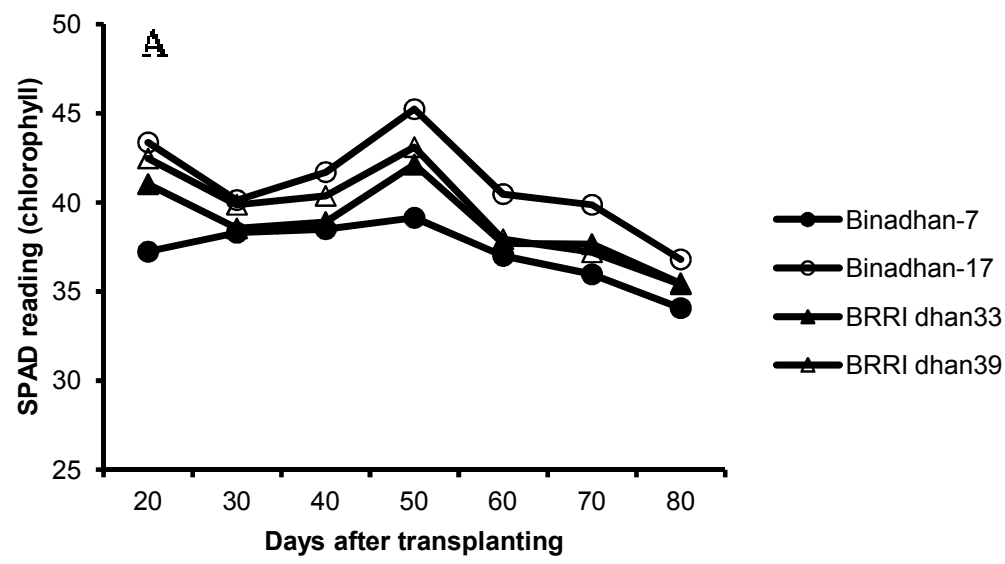




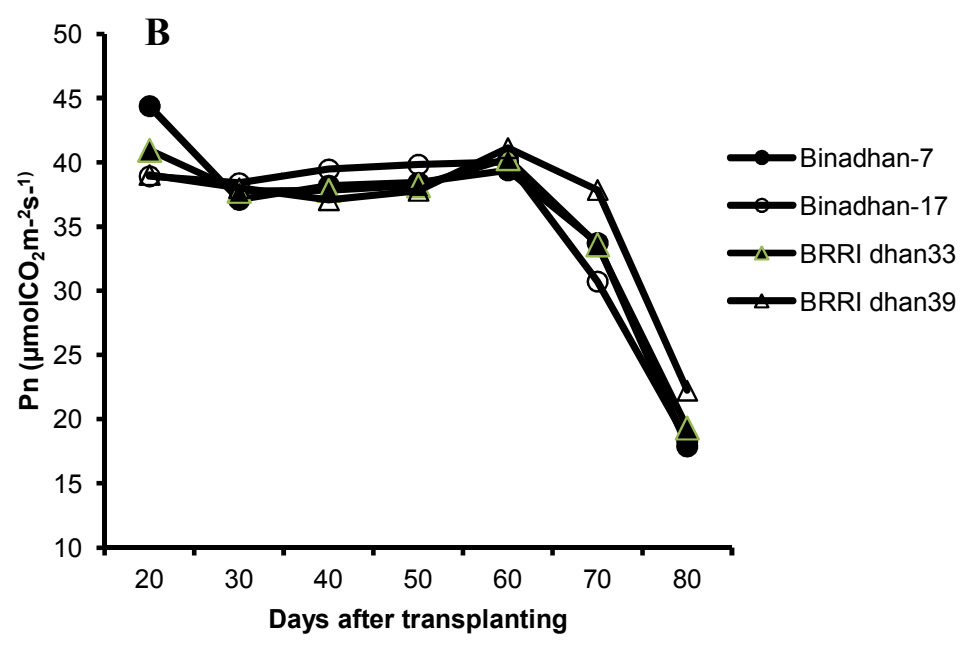

Fig. 5. Ontogenetic A. Chlorophyll content B. Photosynthetic rate at different DAT of four rice varieties at Mymensingh

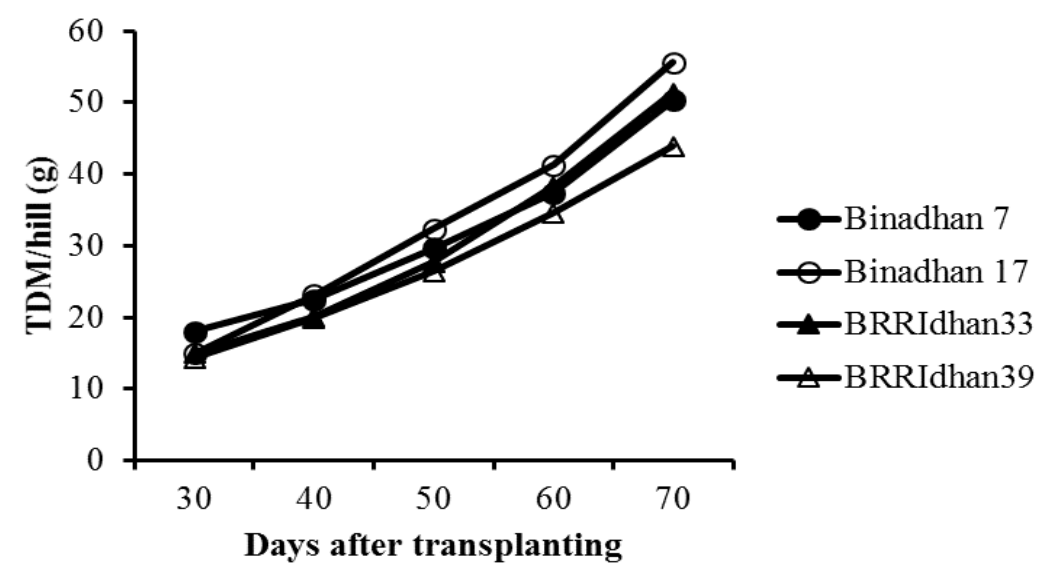

Fig. 6. Total dry mass production at different growth stages in four rice varieties

The total dry matter (TDM) production in rice varieties increased with age up to maturity but TDM accumulation was rapid up to 70 DAT followed by slowly increase up to physiological maturity (Fig. 6). Binadhan-17 maintained the highest TDM and the lowest TDM was recorded in BRRI dhan39 at all growth stages that was probably due to better photosynthesis rate and chlorophyll content in leaves [43]. In contrast, Binadhan-17 showed rapid growth and development at different growth stages (Fig. 7) except 40-50 DAT accumulates dry matter in shortest possible time for higher grain yield. Considering the dry matter and absolute growth rate, results indicated that Binadhan-17 showed positively and significantly higher dry matter production and rapid growth which might help in increased higher grain yield.
The difference of large vascular bundles of the uppermost internodes and pith cavity among different varieties was perceived by microscopic observation. The numbers of large vascular bundles were increased along with the increased diameters of the $1^{\text {st }}$ internodes and pith cavity in Binadhan-17 followed by BRRI dhan33 (Fig. 8 A \& B) that improved stem strength and reduced lodging risk. The vascular bundle system of the culms provides stronger mechanical support in shorter rice plants $[44,45]$ that may help against the lodging and inhibit assimilates translocation. These results indicated that the meristematic activity and cell proliferation enhances plant growth for better photosynthesis and dry matter accumulation of Binadhan-17 which ultimately contributes to yield. 
Akter et al.; ARRB, 32(5): 1-13, 2019; Article no.ARRB. 50288

Table 4. Yield and yield contributing characters of four early maturing rice varieties

\begin{tabular}{|c|c|c|c|c|c|c|c|c|}
\hline \multirow[t]{2}{*}{ Varieties } & \multirow{2}{*}{$\begin{array}{l}\text { Panicle } \\
\text { length }(\mathrm{cm})\end{array}$} & \multirow{2}{*}{$\begin{array}{l}\text { Grains } \\
\text { panicle }^{-1}\end{array}$} & \multirow{2}{*}{$\begin{array}{l}\text { Unfilled grains } \\
\text { panicle }^{-1}\end{array}$} & \multirow{2}{*}{$\begin{array}{l}\text { 1000- grain } \\
\text { weight }(g)\end{array}$} & \multicolumn{4}{|c|}{ Seed yield $\left(\mathrm{t} \mathrm{ha}^{-1}\right)$} \\
\hline & & & & & Mymensingh & Ishurdi & Magura & Mean \\
\hline Binadhan-7 & $24.37 \mathrm{~b}$ & $122.1 \mathrm{c}$ & $20.89 c$ & $21.72 \mathrm{c}$ & $3.90 \mathrm{~b}$ & $4.77 \mathrm{c}$ & $3.99 \mathrm{~b}$ & $4.22 \mathrm{c}$ \\
\hline Binadhan-17 & $22.86 \mathrm{c}$ & $175.2 \mathrm{a}$ & $26.89 \mathrm{~b}$ & $20.28 d$ & $4.32 \mathrm{a}$ & $6.17 \mathrm{a}$ & $4.73 \mathrm{a}$ & $5.07 \mathrm{a}$ \\
\hline BRRI dhan33 & $25.38 a b$ & $136.3 \mathrm{~b}$ & $36.00 \mathrm{a}$ & $24.10 \mathrm{a}$ & $4.33 \mathrm{a}$ & $5.57 \mathrm{~b}$ & $4.60 \mathrm{a}$ & $4.83 \mathrm{~b}$ \\
\hline BRRI dhan39 & $26.47 \mathrm{a}$ & $143.4 \mathrm{~b}$ & $35.56 \mathrm{a}$ & $23.11 b$ & $4.16 a b$ & $4.97 \mathrm{c}$ & $3.47 \mathrm{c}$ & $4.20 \mathrm{c}$ \\
\hline CV\% & 4.82 & 7.83 & 11.07 & 4.44 & 4.70 & 5.10 & 6.54 & 5.45 \\
\hline
\end{tabular}

Common letter(s) in a column on specific treatment do not differ significantly at 5\% level as per DMRT 


\subsection{Yield and Yield Contributing Traits}

The variation in yield and yield attributes of the varieties were significant. It was reported that rice production increased due to selecting yield and yield contributing characters during the course of rice cultivation [4] and can be estimated on the performance of panicle length, grain number per panicle, grain size, grain fertility, 1000-seed weight and rachis branches of the panicle [5]. Variations of yield contributing characters such as panicle length, number of fill and un-fill grains/panicle and 1000-grain weight was significant (Table 4). BRRIdhan39 produced the longest panicle and Binadhan-17 had shorter panicles with greater number of grains per

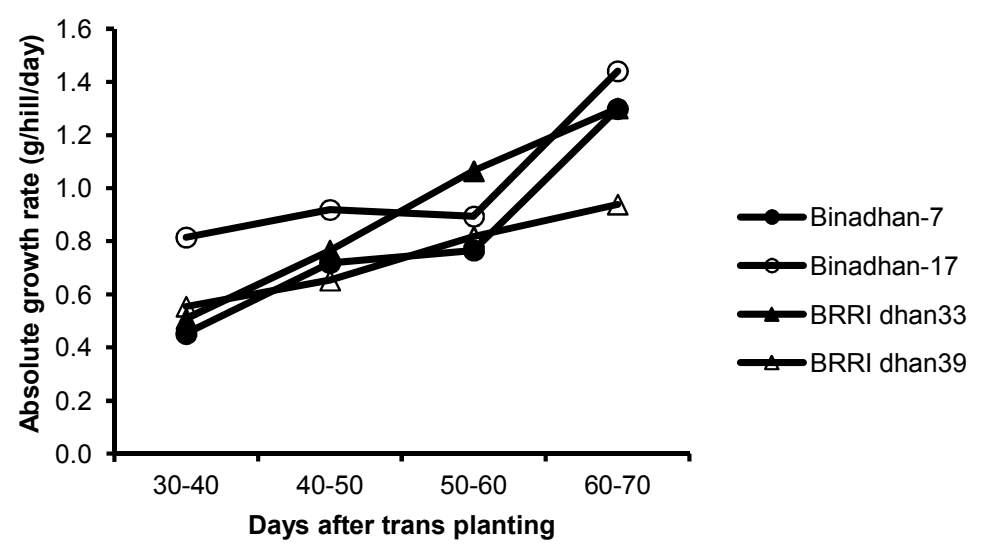

Fig. 7. Plant growth rate per day at different growth stages in four early maturing rice varieties

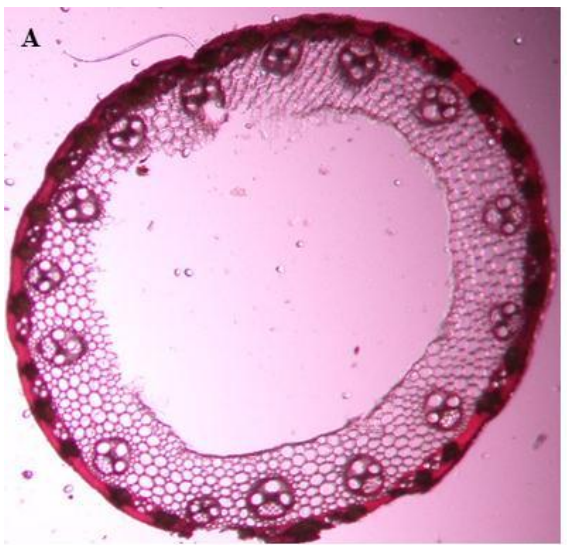

Binadhan-7

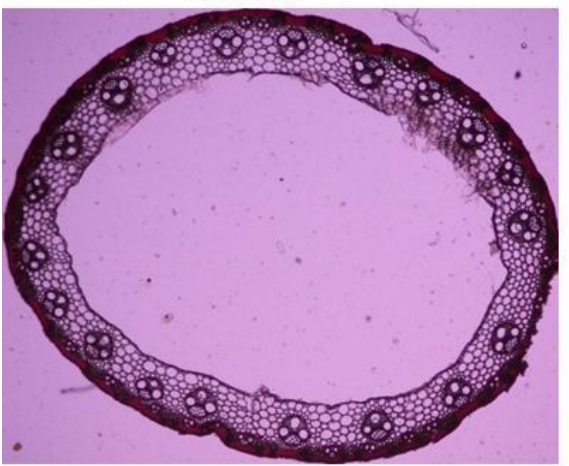

BRRI dhan 33

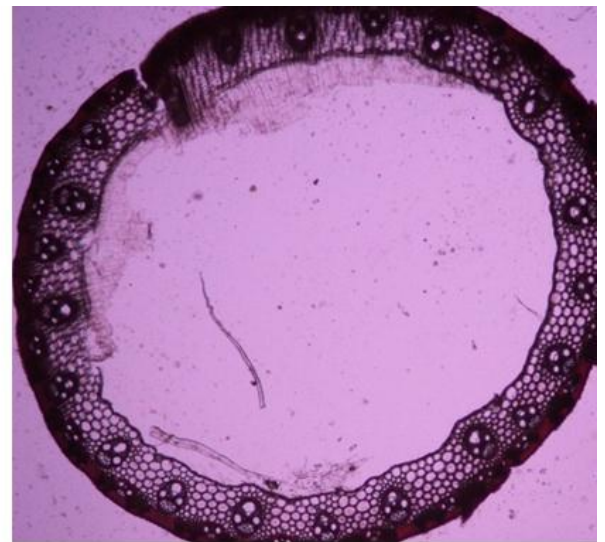

Binadhan-17

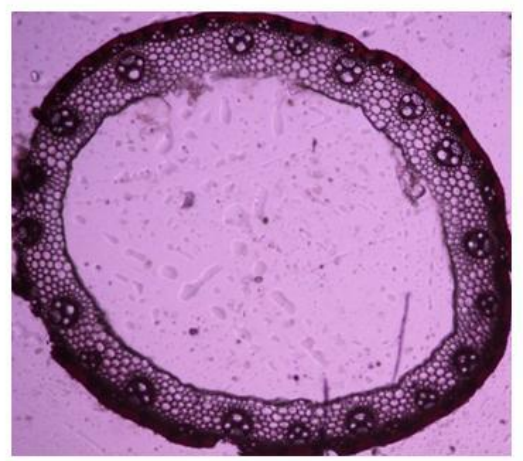

BRRI dhan39 


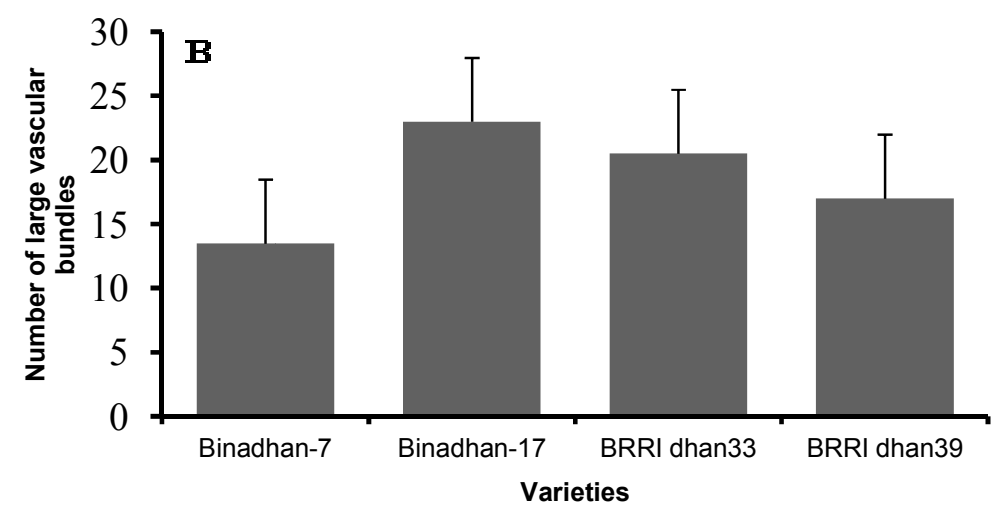

Fig. 8. Microscopic observations; A. Cross-section of the 1st internode B. The number of large vascular bundles

panicle. The lowest unfilled grains/panicle was recorded in Binadhan-7 followed by Binadhan-17 and the highest number of unfilled grain was recorded in BRRI dhan33 (Table 4). BRRI dhan33 produced comparatively coarse grains as compared to others, whereas Binadhan-17 produced fine grain. Besides, Binadhan-17 showed higher number of rachis branches as compared to other three varieties (Fig. 9). The highest grain yield was recorded in Binadhan-17 at all three locations. Binadhan-7 and BRRI dhan39 produced the lowest mean grain yield. The grain yield was higher in Binadhan-17 might be due to increase grain number/panicle, higher number of secondary rachis branches (Fig. 9 and Table 4). These data suggests that the yield can be increased with the increased grains per panicle and secondary branches in rice.
Dry matter allocation per spikelet from heading to maturity was important for higher grain yield in rice. The poor grain filling might be related to poor partitioning of assimilates to the grain in rice [41]. Total dry mass production and its distribution into seed yield per plant were found in Binadhan-17 followed by BRRI dhan33. Besides, BRRI dhan39 produced comparatively the low yield with lowest TDM over its growth period (Fig. 6). It is observed that the grain yield increased with increased total dry matter production and grain yield strongly correlated with total dry mass production (Fig. 10). These results indicated that higher dry matter production during grain filling is helpful for grain filling in rice that also previously reported by Yang et al. [46].
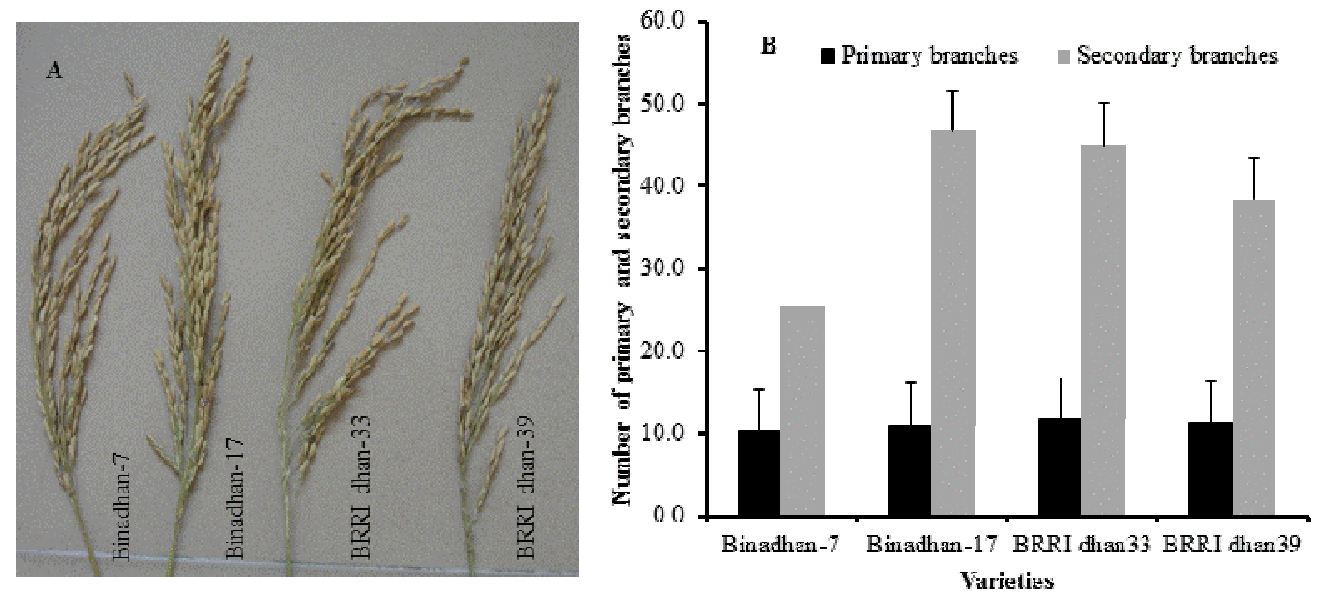

Fig. 9. Panicle characterization; A. Panicle architecture B. Variations in primary and secondary branches of early maturing four rice varieties 


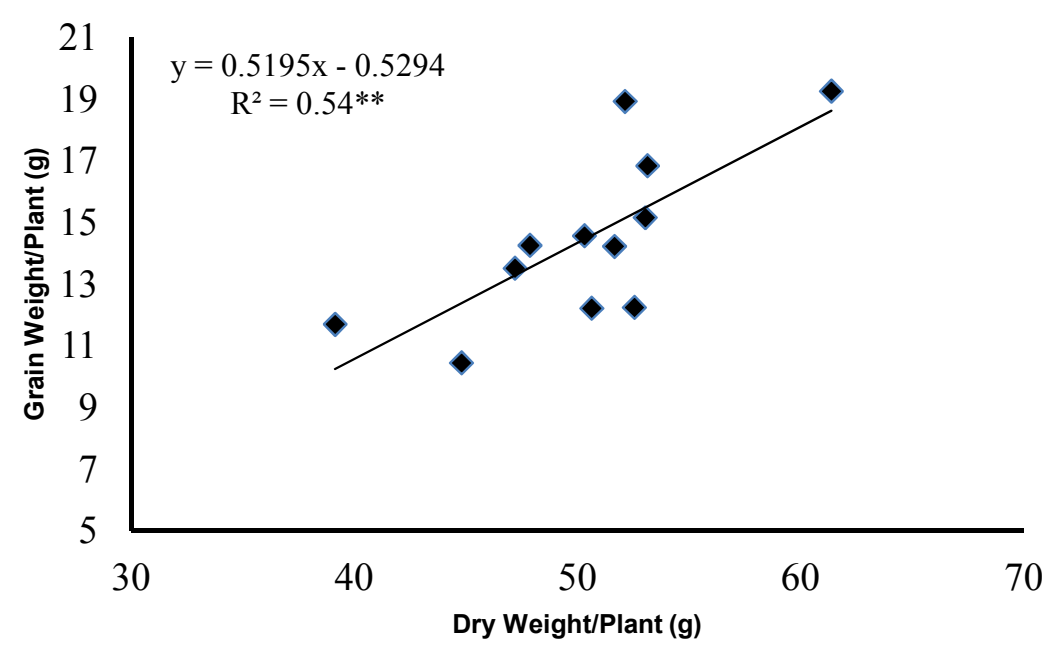

Fig. 10. Relationship between dry weight and grain weight per plant

\section{CONCLUSIONS}

The variety, which had rapid growth and development at early growth, stages, better dry matter partitioning to economic yield also showed higher grain yield. Binadhan-17 showed superiority in early growth and development resulting from higher number of vascular bundles that promotes dry matter accumulation. In addition, grain yield is increased mainly due to increase grain number per panicle, higher number of secondary rachis branches. This information may be helpful for breeders for developing superior rice varieties.

\section{ACKNOWLEDGEMENT}

This work was supported by SRSD project, Ministry of Agriculture, The People's Republic of Bangladesh. The authors would like to thank Horticulture division, BINA for providing their microscope.

\section{COMPETING INTERESTS}

Authors have declared that no competing interests exist.

\section{REFERENCES}

1. Food and Agriculture Organization (FAO) FAOSTAT. Annual Report. FAO: Rome, Italy; 2011.

Available online: http://www.fao.org

2. Yang J, Zhang J. Grain-filling problem in 'super' rice. J. Exp. Bot. 2010;61(1):1-5.
3. Shi J, Li R, Qu D, Jiang C, Long $Y$, Morgan C, Bancroft I, Zhao J, Meng J. Unraveling the complex trait of crop yield with quantitative trait loci mapping in Brassica napus. Genetics. 2009;182: 851-861.

4. Wang $\mathrm{Y}, \mathrm{Li} \mathrm{J}$. Molecular basis of plant architecture. Annu. Rev. Plant Biol. 2008; 59:253-279.

5. Yan WH, Liu HY, Zhou XC, Li QP, Zhang J, Lu L, Liu TM, Liu HJ, Zhang CJ, Zhang ZY, Shen GJ, Yao W, Chen HX, Yu SB, Xie WB, Xing YZ. Natural variation in Ghd 7.1 plays an important role in grain yield and adaptation in rice. Cell Res. 2013; 23:969-971.

6. Wu X. Prospects of developing hybrid rice with super high yield. Agron. J. 2009;101:688-695.

7. Selvaraj IC, Nagarajan P, Thiyagarajan K, Bharathi M, Rabindran R. Genetic parameters of variability, correlation and path coefficient studies for grain yield and other yield attributes among rice blast disease resistant genotypes of rice (Oryza sativa L.). Afr. J. Biotechnol. 2011; 10:3322-3334.

8. Puteh $A B$, Saragih $A A$, Ismail MR, Mondal MMA. Grain yield of cultivated and weedy rice to water stress at reproductive stage. J. Food Agric. Environ. 2013;11(2):742746.

9. Akter MB, Kim B, Lee Y, Koh E, Koh HJ. Fine mapping and candidate gene analysis of a new mutant gene for panicle apical 
abortion in rice. Euphytica. 2014;197:387398.

10. Babu VR, Shreya K, Dangi KS, Usharani G, Nagesh P. Genetic variability studies for qualitative and quantitative traits in popular rice (Oryza sativa L.) hybrids of India. Inter. J. Sci. Res. Publications. 2012;2(6):1-5.

11. Berahim Z, Ismail MR, Halimi MS, Mondal MMA, Panhwar QA, Islam MR. Effectiveness of different phytohormones on grain filling and yield of rice under drought stress. J. Food Agric. Environ. 2014;12(2):697-700.

12. Xue $W$, Xing $Y$, Weng $X$, Zhao $Y$, Tang $W$. Natural variation in Ghd7 is an important regulator of heading date and yield potential in rice. Nat. Genet. 2008;40:761767.

13. Takeda K. Internode elongation and dwarfism in some gramineous plants. Gamma Field Symp. 1977;16:1-18.

14. Sharma AP, Singh SP. Relationship of physiological attributes with grain yield in rice. Agric. Sci. Digest. 2000;20(3):191192.

15. Islam MT. Photosynthesis, conductance, transpiration, water use efficiency and grain growth of high yielding rice varieties under water stress. Int. J. Expt. Agric. 2010;1(2):10-14.

16. Gorney AG, Larson $S$. New aspect in root breeding. Proc. III. Congress of Eucarpia Goltingen, Germany. 1989;339-356.

17. Flood RG, Martin PJ, Gardner WK. Dry matter accumulation and partitioning and its relationship to grain yield in wheat. Aust. J. Exp. Agric. 1995;35:495-502.

18. Mondal MMA, Puteh AB, Malek MA, Ismail MR, Rafii MY, Latif MA. Seed yield in relation to growth and developmental aspects of mungbean. The Scientific World J; 2012.

DOI:10.1100/2012/425168

19. Peng S, Khush GS, Virk P, Tang Q, Zou Y. Progress in ideotype breeding to increase yield potential. Field Crops Res. 2008;108:32-38.

20. Masuda T, Fujita Y. Regulation and evolution of chlorophyll metabolism. Photochem. Photobiol. Sci. 2008;7:11311149.

21. Saragih $A A$, Puteh $A B$, Ismail $M R$, Mondal MMA. Pollen quality traits of cultivated and weedy rice to water stress at reproductive stage. Aust. J. Crop Sci. 2013;7:1106-11.

22. Yoshida $\mathrm{H}$, Horie $\mathrm{T}$. A process model for explaining genotypic and environmental variation in growth and yield of rice based on measured plant $\mathrm{N}$ accumulation. Field crops res. 2009; 113(3):227-37.

23. Ambavaram MMR, Basu S, Krishnan A, Ramegowda V, Batlang U, Rahman L, Baisakh N, Pereira A. Coordinated regulation of photosynthesis in rice increases yield and tolerance to environmental stress. Nature Communications, 2014;5:5302.

24. Takai T, Adachi S, Taguchi-Shiobara F, Sanoh-Arai $Y$, Iwasawa N, Yoshinaga $S$, Hirose S, Taniguchi Y, Yamanouchi U, Wu J. A natural variant of NAL1, selected in high-yield rice breeding programs, pleiotropically increases photosynthesis rate. Sci. Rep. 2013;3:2149.

25. Huang $L$, Dai $L$, Wang $L$, Leng $Y$, Yang $Y$, Xu J, Hu J, Rao Y, Zhang G, Zhu L, Dong G. Genetic dissection for chlorophyll content of the top three leaves during grain filling in rice (Oryza sativa L.). J. Plant Growth Regul. 2015;34(2):38191.

26. Makino A. Photosynthesis, grain yield and nitrogen utilization in rice and wheat. Plant Physiol. 2011;155(1):125-129.

27. Davood BT, Ali G, Hemmal AP, Morteza N. Flag leaf morphophysiological response to different agronomical treatment in a promising line of rice (Oryza sativa L.). American- Eurasian J. Agric. Environ. Sci. 2009;5(3):403-408.

28. Chang S, Chang T, Song Q, Zhu XG, Deng $Q$. Photosynthetic and agronomic traits of an elite hybrid rice Y-Liang-You 900 with a record-high yield. Field Crops Res. 2016;187:49-57.

29. Badger MR. Role of plant leaf development in optimising photosynthetic efficiency, capacity, growth and yield. Applying photosynthesis research to improvement of food crops. 2013;20.

30. Togay N, Togay Y, Yildirin B, Dogan Y. Relationships between yield and some yield components in pea (Pisum sativum subsp. arvense L.) genotypes by using correlation and path analysis. Afr. J. Biotechnol. 2008;7(23):4285-4287.

31. Ali MA, Nawad NN, Abbas A, Zulkiffal M, Sajjad M. Evaluation of selection criteria in Cicerarietinum L. using correlation coefficients and path analysis. Aust. J. Crop Sci. 2009;3(2):65-70.

32. BARC. Fertilizer Recommendation Guide (FRG). Bangladesh Agricultural Research Council, Dhaka; 2012. 
33. Kato $\mathrm{Y}$, Kamoshita A, Yamagishi J, Imoto $\mathrm{H}$, Abe J. Growth of rice (Oryza sativa L.) cultivars under upland conditions with different levels of water supply 3 . Root system development, soil moisture changeand plant water status, Plant Prod. Sci. 2007;10(1):3-13.

34. Akter MB, Piao R, Reflinur, Rahman ML, Lee $Y$, Seo J, Kim B, Koh HJ. Characterization and mapping of $d 13$, a dwarfing mutant gene, in rice. Genes Genom. 2015;37:893.

35. Gutam S. Dry matter partitioning, grain filling and grain yield in wheat genotype. Communications Biometry Crop Sci. 2011;6(2):48-63.

36. Russell DF. MSTAT-C Pakage Programme. Crop and soil science department, Michigan University, USA; 1986.

37. Mazid MS, Rafii MY, Hanafi MM, Rahim HA, Latif MA. Genetic variation, heritability, divergence and biomass accumulation of rice genotypes resistant to bacterial blight revealed by quantitative traits and ISSR markers. Physiol. Plant, 2013;149(3):432447.

38. Fageria NK. Yield physiology of rice. J. Plant Nutri. 2007;30:843-879.

39. Prakash M, Anandan A, Kumar SB. Varietal variations in flag leaf area and yield in mutant lines of py5 rice. Karmataka J. Agric. Sci. 2011;24(4):525-526.

40. Jeng TL, Tseng TH, Wang CS, Chen CL, Sung JM. Yield and grain uniformity in contrasting rice genotypes suitable for different growth environments. Field Crops Res. 2006;99(1):59-66.

41. Puteh $A B$, Mondal MMA, Ismail MR, Latif MA. Grain sterility in relation to dry mass production and distribution of rice. Biomed Res; 2014. Intl. dx.

DOl.org/10.1155/2014/302179

42. Ohsumi A, Hamasaki A, Nakagawa $H$, Yoshida $H$, Shiraiwa T, Horie T. A model explaining genotypic and ontogenetic variation of leaf photosynthetic rate in rice (Oryza sativa) based on leaf nitrogen content and stomatal conductance. Ann Bot. 2007;99:265-273.

43. Mondal MAA, Puteh AB, Malek MA, Rafii MY. Contribution of morpho-physiological attributes on yield in lentil. Plant Omics. 2013;7:1503-1507.

44. Teale WD, Paponov IA, Palme K. Auxin in action: Signalling, transport and the control of plant growth and development. Nat. Rev. Mol. Cell Biol. 2006;7:847-859.

45. Aohara T, Kotake T, Kaneko Y, Takatsuji $H$, Tsumuraya $Y$, Kawasaki S. Rice BRITTLE CULM 5 (BRITTLE NODE) is involved in secondary cell wall formation in the sclerenchyma tissue of nodes. Plant Cell Physiol. 2009;50:1886-1897.

46. Yang J, Peng S, Zhang Z, Wang Z, Visperas RM, Zhu Q. Grain and dry matter yields and partitioning of assimilate in japonica/indica hybrid rice. Crop Sci. 2002;42(3):766-772.

(c) 2019 Akter et al.; This is an Open Access article distributed under the terms of the Creative Commons Attribution License (http://creativecommons.org/licenses/by/4.0), which permits unrestricted use, distribution, and reproduction in any medium, provided the original work is properly cited.

Peer-review history:

The peer review history for this paper can be accessed here: http://www.sdiarticle3.com/review-history/50288 